\title{
Зміни патерну дихання, газообміну та мітохондріального окисного фосфорилювання в скелетному м'язі щурів при моделюванні фізичного навантаження
}

\author{
удк 612.741.067: (612.22.062+576.311.347) \\ 'В. І. Портніченко, ${ }^{2}$ М. Г. Колчева, 2 Л. В. Братусь,
'І. О. Назарук, ${ }^{2}$ В. І. Носарь, 2 I. М. Маньковська
}

${ }^{1}$ Міжнародний центр астрономічних та медико-екологічних досліджень НАН України, Київ, Україна

${ }^{2}$ Інститут фізіології ім. О.О. Богомольця НАН України, Київ, Україна

Резюме. Цель. Разработать экспериментальную модель, позволяющую исследовать влияние физической нагрузки на регуляцию паттерна дыхания, газообмена, дыхания митохондрий у наркотизированных животных в условиях острого эксперимента.

Методы. У 6-месячных крыс линии Вистар паттерн дыхания и газообмена регистрировали с помощью автоматизированной установки в составе масс-спектрометра и пневмотахографа. Митохондрии скелетных мышц выделяли методом дифференциального центрифугирования. Функциональное состояние митохондрий исследовали по методу Чанса и Вильямса. Результаты. Выявлены две стратегии ответа на имитированную физическую нагрузку - с гипер- и гипофункцией системы дыхания (I и II). Во время физической нагрузки наблюдалась гипервентиляция, гипертермическая реакция у крыс I группы; гиповентиляционная, гипотермическая реакция у крыс II группы. Экспериментальные животные I группы почти полностью восстановили показатели внешнего и митохондриального дыхания в ближайший период восстановления, у животных II группы восстановление не наблюдалось.

Выводы. Первый тип ответа на стимуляцию $m$. gastrocnemius связан с незначительным ростом употребления кислорода, ростом вентиляционных показателей дыхания, гипертермической реакцией. Второй тип ответа связан со снижением потребления кислорода, снижением вентиляционных и временных показателей дыхания, гипотермической реакцией, ростом вентиляционного эквивалента.

Ключевые слова: дыхание, газообмен, митохондрии, мышцы, нагрузка.

Abstract. Aim. To develop an experimental model to investigate the effect of exercise on the regulation of the pattern of breathing, gas exchange, mitochondrial respiration in anesthetized animals in acute experiment condition.

Methods. In 6 manth old Male Wistar rats the pattern of breathing and gas exchange were recorded using the automatic installation as part of a mass spectrometer and a pneumotachograph. The mitochondria of skeletal muscles were isolated by the method of differential centrifugation. The mitochondria functional state was investigated by the method of Chance and Williams.

Result. Two strategies of response have been identified as hyper- and hypofunction of respiratory system (I and II groups). During exercise hyperventilation and hyperthermic reaction were observed in I group of rats; hypoventilation and hypothermic reaction were observed in II group of rats. Experimental animals of I group restored parameters of external and mitochondrial respiration almost completely in the immediate recovery period, in II group of animals the restoration wasn't observed. Conclusion. The first type of response to $\mathrm{m}$. gastrocnemius stimulation is associated whith a slight increase of the oxygen consumption, increase of ventilation parameters of breathing, hyperthermic reaction. The second type of response is associated with reduced of the oxygen consumption, decreased of ventilation and time parameters of breathing, hypothermic reaction, increase of ventilation equivalent. Keywords: breathing, mitochondria, gas exchange, muscles, exercise. 
Постановка проблеми. Аналіз останніх досліджень і публікацій. Оскільки основним джерелом енергії для життєдіяльності ссавців $є$ процеси біологічного окиснення, то працездатність в умовах м'язової активності нерозривно пов'язана $з$ фрункцією дихання. Легенева вентиляція $€$ першою ланкою в процесі доставки кисню до робочих м'язів і останньою ланкою в процесі виведення із організму продуктів окиснення. Дослідження фрункцій легеневого дихання при м'язовій активності $€$ одним із найбільш доступних і водночас точних та інформативних способів реєстрації змін у процесах енергетичного обміну, що дає можливість оцінювати стан здоров'я і фрізичну працездатність людини $[1,3,15]$.

Сьогодні використовують різні моделі стимуляції м'яза для дослідження фуннкцій і регуляції м'язової системи у ссавців [4, 12]. Однак відсутні чіткі експериментальні моделі дослідження взаємозв'язку всіх оксигентранспортуючих систем організму під час фрізичного навантаження. Існує потреба у створенні таких моделей, що відтворюються на лабораторних тваринах, оскільки інструментальні та біохімічні дослідження на людях мають ряд обмежень.

У сучасних умовах підготовки спортсменів різної спортивної спеціалізації зростають вимоги до підтримки їхньої працездатності, використання науково обгрунтованих методик щодо реабілітації та відновлення. Зниження адаптивних можливостей скелетних м'язів до значних фрізичних навантажень, що $€$ неадекватними функціональному стану організму, спричиняє зниження фрізичної працездатності та може призвести до пошкоджень тканини [9, 11, 12].

Роботу виконано згідно зі Зведеним планом НДР у сорері фрізичної культури і спорту на 20112015 рр. Міністерства освіти і науки, молоді та спорту України за темою «Механізми змін функцінального стану і структурної організації мітохондрій при оксидативному стресі різного генезу» (номер держреєстрації 0112U00823).

Мета дослідження - розробити експериментальну модель дослідження впливу фрізичного навантаження на регуляцію патерну дихання, газообміну, енергетичного метаболізму, дихання мітохондрій у наркотизованих експериментальних тварин в умовах гострого досліду.

Методи і організація дослідження. Досліджували попередньо нетренованих 6-місячних щурів-самців лінії Вістар масою 270-300 г ( $=11)$, на яких проводили стимуляцію триголового м'яза литки дротовими електродами 3 невеличким крючком на кінчику, який вводили до м'яза за допомогою медичної голки. Стимуляцію м'язів проводили універсальним електростимулятором ЕСУ-2. Використовували наступний патерн стимуляції: упродовж 15 хв литковий м'яз лівої кінцівки ( $m$. gastrocnemius) стимулювали пачками імпульсів по 40 с, напругою 10 В, силою току приблизно $2 \mathrm{~mA}$ з перервою на 20 с (у міру втомлення м'яза напругу стимуляції підвищували).

Патерн дихання і газообміну реєстрували за допомогою оригінальної автоматизованої установки [7] у наркотизованих щурів (хлоралозоуретановий 500/50 мг на 1 кг маси тіла), яким здійснювали трахеотомію, фріксували лігатурами трахеостомічну канюлю і приєднували її до пневмотахографра та маспектрометра. Реєстрували такі об'ємно-часові параметри зовнішнього дихання: дихальний об'єм (VT), частота дихання (f), хвилинний об'єм дихання $\left(\mathrm{V}_{\mathrm{E}}\right)$, парціальний тиск $\mathrm{CO}_{2}$ в альвеолярному газі - $\mathrm{pA}_{\mathrm{CO}_{2}}$ (мм рт.ст), парціальний тиск $\mathrm{O}_{2}$ в альвеолярному газі $-\mathrm{pA}_{\mathrm{O}_{2}}$ (мм рт.ст), альвеолярна вентиляція $\left(\mathrm{V}_{\mathrm{A}}\right)$, споживання кисню $-\grave{\mathrm{VO}}_{2}\left(\right.$ мл $\left.\cdot \mathrm{xв} \cdot \mathrm{K \Gamma}^{-1}\right)$, об'єм $\mathrm{CO}_{2}$, що виділяється $-\mathrm{VCO}_{2}\left(\right.$ мл $\left.\cdot \mathrm{xв} \cdot \mathrm{k}^{-1}\right)$, вентиляційний еквівалент $\left(\mathrm{V}_{\mathrm{E}} / \mathrm{VO}_{2}\right)$. Показники об'ємів приводили до системи BTPS, показники газообміну - до системи STPD. $\mathrm{VO}_{2}$ визначали шляхом інтегрування концентрації $\mathrm{O}_{2}$ у видихуваному повітрі [7]. Розраховували швидкість доставки $\mathrm{O}_{2}$ в альвеоли і відсоток екстракції $\mathrm{O}_{2} 3$ альвеол [6].

Мітохондрії скелетних м'язів виділяли методом диференційного центрифугування за умов, в яких зберігалась їхня нативність. Функціональний стан мітохондрій досліджували методами Чанса і Вільямса $[10,17]$. Показники системи мітохондріального енергозабезпечення $m$. gastrocnemius визначались одразу після 15 хв стимуляції та через 15 хв відновлення після стимуляції. Контролем слугував не стимульований м'яз іншої кінцівки. Як субстрат окиснення використовували сукцинат натрія - 5 ммоль. Дихання стимулювали 200 ммоль АДФ. Використовуючи одержані полярограми, обчислювали параметри дихання мітохондрій (за Чансом): у стані спокою $\left(\mathrm{V}_{4}^{\mathrm{s}}\right)$, у стані активного дихання при додаванні АДФ $\left(\mathrm{V}_{3}\right)$ та контрольованого дихання $\left(\mathrm{V}_{4}{ }^{\mathrm{AT \Phi}}\right)$, дихальний контроль $\left(\mathrm{V}_{3} /\right.$ $\mathrm{V}_{4}^{\mathrm{AT \Phi}}$ ), коесріцієнт ефрективності фосфрорилювання (ӒДФ/O).

Температуру тіла визначали ректально за допомогою електротермометра. Статистичну обробку результатів виконували за допомогою «Microsoft Excel». Вірогідність одержаних даних оцінювали за допомогою критерію Стьюдента на програмному комплексі «V-Stat».

Результати дослідження та їх обговорення. Об'ємно-часові параметри зовнішнього дихання. При застосуванні моделі м'язового 
ТАБЛИЦЯ 1 - Вихідні показники дихання експериментальних тварин до фізичного навантаження, $\mathrm{M} \pm \mathrm{m}$

\begin{tabular}{|c|c|c|}
\hline Показник & $\begin{array}{c}\text { Група I, } \\
\text { n = } 6\end{array}$ & $\begin{array}{c}\text { Група II, } \\
\text { n = }\end{array}$ \\
\hline $\mathrm{V}_{\mathrm{E}}\left(\mathrm{M} Л \cdot \mathrm{XB}^{-1} \cdot \mathrm{\kappa} \Gamma^{-1}\right)$ & $310,54 \pm 4,05$ & $312,95 \pm 5,8$ \\
\hline $\mathrm{VT}($ мл $\cdot$ кГ-1) & $4,4 \pm 0,3$ & $4,8 \pm 0,2$ \\
\hline$f\left(X B^{-1}\right)$ & $66,33 \pm 2,2$ & $69 \pm 1,7$ \\
\hline $\mathrm{VO}_{2}\left(\mathrm{M} \cdot \mathrm{K}^{-1}\right)$ & $12,23 \pm 0,5$ & $12,25 \pm 0,5$ \\
\hline $\mathrm{VCO}_{2}\left(\mathrm{мл} \cdot \mathrm{K} \Gamma^{-1}\right)$ & $13,13 \pm 0,9$ & $12,58 \pm 1,15$ \\
\hline pA $\mathrm{O}_{2}$ (мм рт.ст.) & $99,24 \pm 0,5$ & $99,82 \pm 1,8$ \\
\hline pA CO${ }_{2}$ (мм рт.ст.) & $45,18 \pm 0,6$ & $44,87 \pm 3,8$ \\
\hline $\mathrm{V}_{\mathrm{A}}\left(\mathrm{M} \Omega \cdot \mathrm{XB}^{-1} \cdot \mathrm{K}^{-1}\right)$ & $255,38 \pm 5,93$ & $228,46 \pm 6,12$ \\
\hline $\mathrm{V}_{\mathrm{E}} / \mathrm{NO}_{2}$ & $20,65 \pm 0,05$ & $22,87 \pm 3,18$ \\
\hline
\end{tabular}

* Рівень значущості змін досліджуваних показників при $p<0,05$.

навантаження у щурів спостерігали неоднакову реакцію з боку газообміну, а саме різноспрямований характер споживання кисню (рис. 1), а отже, і неоднозначну відповідь з боку системи дихання. Оскільки показник $\mathrm{VO}_{2}$ характеризує запит, який організм подає системі доставки кисню, саме за цим показником тварин було поділено на дві групи (I і II). Варто зазначити, що до початку стимуляції м'яза показники об'ємно-часових

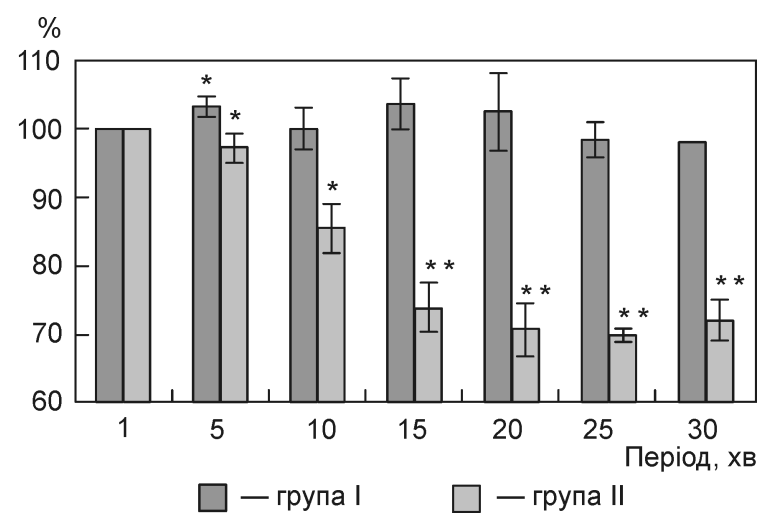

Рисунок 1 - Показники $\dot{\mathrm{V}}_{2}$ упродовж 15 хв стимуляції м'яз та подальших 15 хв періоду відновлення

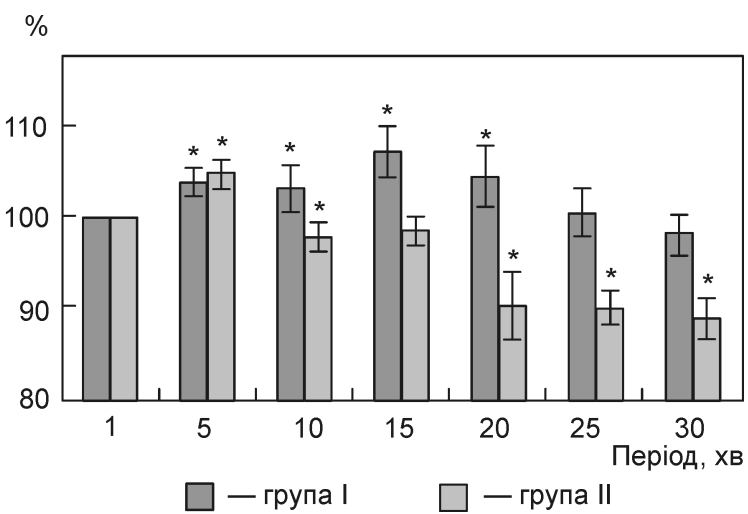

Рисунок 2 - Показники $\mathrm{f}$ упродовж 15 хв стимуляції м'яз та подальших 15 хв періоду відновлення параметрів зовнішнього дихання в обох групах вірогідно не відрізнялися (табл. 1). 3 огляду на це, всі показники дихання відображають зміну у відсотках від значень вихідних показників, одержаних у тварин перед стимуляцією, які приймали за $100 \%$.

Тварини групи I збільшують $\mathfrak{V O}_{2}$ в перші хвилини навантаження (рис. 1). Після п'ятої хвилини показники поверталися до вихідних значень і трималися на цьому рівні впродовж всього досліду.

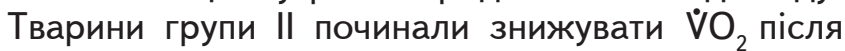
5 хв стимуляції м'яза, цей показник продовжував знижуватися весь подальший період стимуляції і відновлення. На 15 хв стимуляції значення $\mathrm{VO}_{2}$ в групі II знизилося на 22 \%. В групі I $\mathrm{VO}_{2}$ в періоді відновлення не відрізнялося від контролю.

В перші 5 хв стимуляції м'яза в обох групах спостерігали зростання частоти дихання, дихального об'єму і відповідно $\mathrm{V}_{\mathrm{E}}$. Після п'ятої хвилини відбулось зниження показників f i VT (рис. 2 і 3), а в подальші хвилини стимуляції тварини групи I демонстрували зростання $\mathrm{f}$ i VT відповідно $\mathrm{i} \mathrm{V}_{\mathrm{E}}$ (рис. 4). В групі II упродовж подальшого досліду значення $\mathrm{f}$ i VT продовжували знижуватись, внаслідок чого значення $\mathrm{V}_{\mathrm{E}}$ вірогідно знизилося на $19 \%$. В період відновлення в групі I f суттєво не відрізнялася від контролю, а VT знизився до $10 \%$, відповідно знизився і $\mathrm{V}_{\mathrm{E}}$. В групі II частота дихання знизилась на $12 \%$, а V рахунок зниження VT.

Таким чином, перші 5 хв роботи в обох групах супроводжувалися частішим і глибшим диханням. Після 5 хв у тварин групи І було відмічено подальше зростання цих показників. Тварини групи II після 5 хв досліду демонстрували зниження $\mathrm{V}_{\mathrm{E}}$ за рахунок зниження VT, при чому значення $\mathrm{V}_{\mathrm{E}}$ продовжувало знижуватися весь період стимуляції і відновлення (рис. 4).

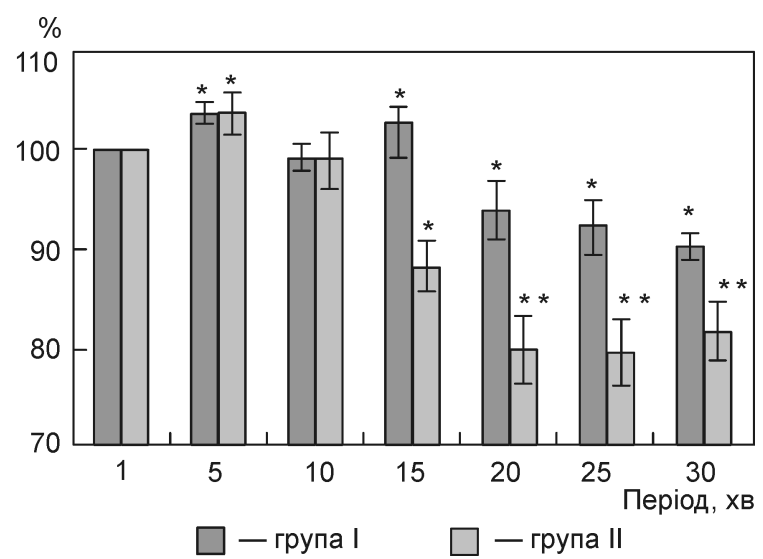

Рисунок 3 - Показники VT упродовж 15 хв стимуляції м'яза та подальших 15 хв періоду відновлення 


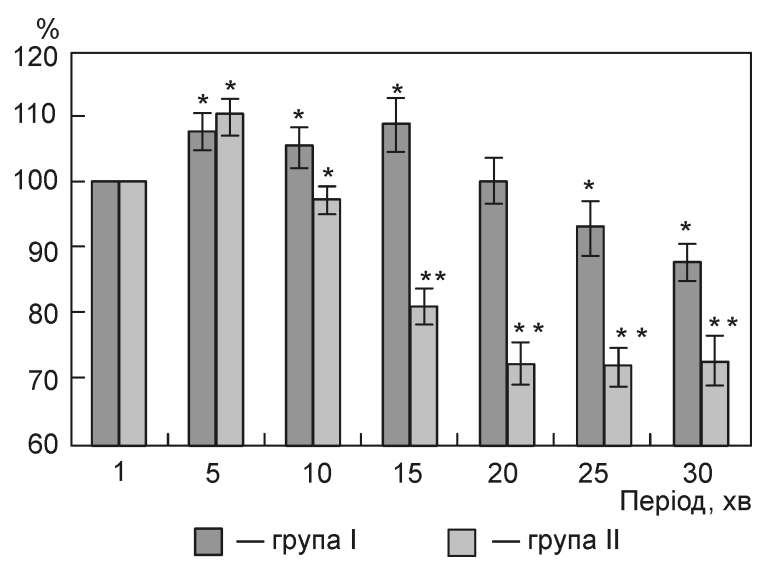

Рисунок 4 - Показники $\mathrm{V}_{\mathrm{E}}$ упродовж 15 хв стимуляції м'яз та подальших 15 хв періоду відновлення

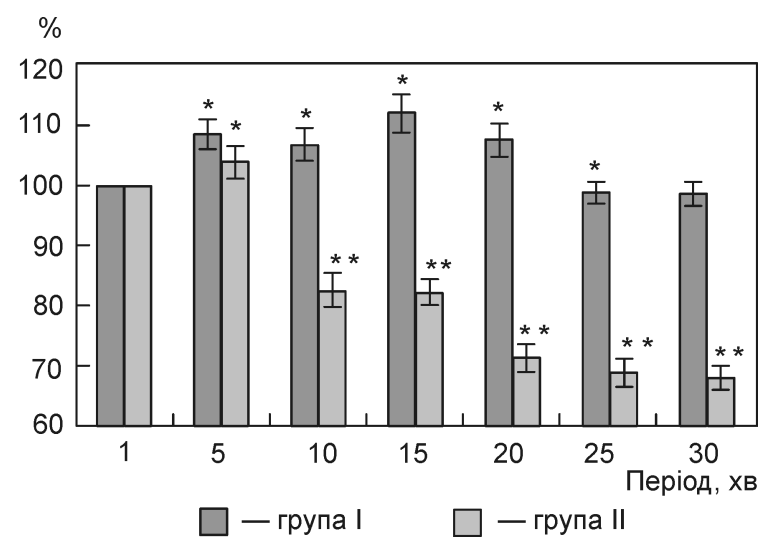

Рисунок 5 - Показники $\mathrm{V}_{\mathrm{A}}$ упродовж 15 хв стимуляції м'яз та подальших 15 хв періоду відновлення

Зміни альвеолярної вентиляції також характеризувалися зростанням впродовж перших 5 хв стимуляції в обох групах тварин. Після 10 хв стимуляції в групі I спостерігали вірогідне зростання альвеолярної вентиляції на 10 \%. У тварин групи II цей показник після п'ятої хвилини роботи м'язу знизився на $13 \%$. В період відновлення альвеолярна вентиляція тварин групи I була на рівні контролю, а в II групі - на 30 \% нижче початкових показників (рис. 5).

Парціальний тиск $\mathrm{O}_{2}$ в альвеолярному газі зростав в обох групах на початку стимуляції, що свідчить про початкову гіпервентиляцію альвеол. Однак, після 5 хв роботи в групі I $\mathrm{P}_{\mathrm{A02}}$ зростав і в період відновлення повертався до вихідних значень. В групі II після 5 хв стимуляції значення $\mathrm{P}_{\mathrm{A02}}$, навпаки, знижувався приблизно на $7 \%$, з подальшим його зростанням. В період відновлення цей показник знаходився у межах контролю (рис. 6).

У тварин групи I не спостерігали суттєвих змін $\mathrm{V}_{\mathrm{E}} / \mathrm{VO}_{2}$ упродовж 15 хв стимуляції, що може свідчити про більшу ефективність вентиляції, ніж у тварин групи II, які демонстрували вірогідне

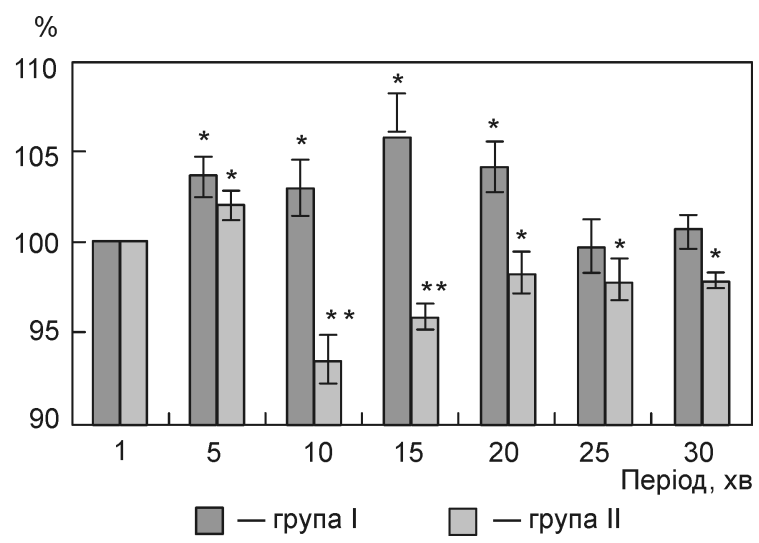

Рисунок 6 - Показники рАО 2 упродовж 15 хв стимуляції м'яз та подальших 15 хв періоду відновлення

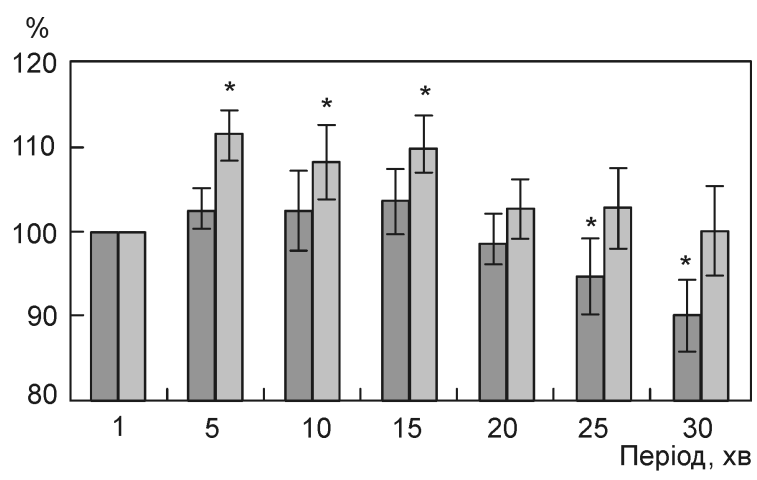

$\square$ - група I $\square$ - група II

Рисунок 7 - Показники $\mathrm{V}_{\mathrm{E}} / \mathrm{V}_{2}$ упродовж 15 хв стимуляції м'яз та подальших 15 хв періоду відновлення

зростання цього показника на $10 \%$. В період відновлення в групі I значення $\mathrm{V}_{\mathrm{E}} / \mathrm{VO}_{2}$ знизилося, порівняно з контрольними значеннями, а в групі II повернувся до вихідних показників (рис. 7).

Показники мітохондріального окисного фоссфорилюВання. Показники системи мітохондріального енергозабезпечення $m$. gastrocnemius через 15 хв відновлення після стимуляції подано в таблиці 2. Отримані дані свідчать про те, що у тварин другої групи в мітохондріях скелетного м'яза відбувалося зниження швидкості АДФ-стимульованого дихання на тлі зростання сукцинатоксидазного окиснення на $18 \%$. Також спостерігалося зменшення спряженості дихання 3 фоссрорилюванням $\left(\mathrm{V}_{3} / \mathrm{V}_{4}\right)$ на $36 \%$ та ефективності використання кисню (АДФ/О) на 13,8 \%, порівняно з контролем.

В I групі не було показано значущих відмінностей між показниками мітохондріального дихання в робочому м'язі і в контрольному, що свідчить про відновлення енергозабезпечуючих процесів після навантаження.

Аналіз показників мітохондріального дихання показав співпадіння зі змінами загального 
споживання $\mathrm{O}_{2}$ організмом. Одні тварини продемонстрували майже повне відновлення показників у найближчому періоді відновлення (група I), а в інших тварин повернення показників до контрольного рівня було відсутнє (група II).

Оскільки задане фрізичне навантаження було низькоінтенсивним, воно не викликало суттєвого зростання $\mathrm{VO}_{2}$ усім організмом i, ймовірно, нівелювалося за рахунок централізації кровообігу, яка супроводжується перерозподілом кровопостачання до активно функціонуючих органів [5].

Такі зміни можуть непрямо свідчити про існування порогового рівня гіпоксії для споживання кисню організмом, при перевищенні якого активується програма дихального центру i $\mathrm{VO}_{2}$ зростає, як при звичайному фрізичному навантаженні. Значну роль в цьому грає сигналізація від хеморецепторного апарату організму про порушення гомеостазу внутрішнього середовища, яка $\epsilon$ стимулом до подальшої активації дихального центру $[1,3,9]$. Оскільки ж рівень гіпоксемії не перевищив порогові значення, то робоча гіпервентиляція, що виникла при відсутності суттєвого зростання $\mathrm{VO}_{2}$, може бути пов'язана з пропріорецептивною стимуляцією дихального центру. Відповідно до даних наукової літератури [1, 3] у розвитку робочої гіпервентиляції бере участь сигналізація від рецепторів працюючого м'яза, а також зв'язок та суглобів. В дослідах на тваринах, у тому числі децереброваних, пасивні рухи кінцівками супроводжувалися гіпервентиляцією, і цей ефект усувався деаферентацією робочої кінцівки.

Про такий механізм непрямо свідчить наявність не ізовентиляторної перебудови патерну дихання, яку пов'язують з активацією хеморецепторів, а стеновентиляторної перебудови дихання, яку ми спостерігаємо в обох групах досліджуваних тварин [2].

Проте одержані нами результати можуть свідчити не про одну, а про дві різні стратегії енергетичного забезпечення робочого м'яза в двох групах тварин, і викладене вище обговорення стосується лише першої групи щурів.

В другій групі щурів після початкового зростання спостерігається пригнічення зовнішнього дихання і газообміну, що підтверджується і даними щодо мітохондріального дихання тканини м'язів. Це пригнічення простежується і в найближчий період відновлення після фрізичного навантаження. Складається враження, що після первинного зростання дихання у цих тварин, далі розвивається гіпометаболічна реакція, при якій ефрективність фросфорилювання в мітохондріях робочого м'яза підвищується.
ТАБЛИЦЯ 2 - Показники окисного фосфорилювання m. gastrocnemius, $\mathrm{M} \pm \mathrm{m}$

\begin{tabular}{|l|c|c|c|c|}
\hline \multirow{2}{*}{ Показник } & \multicolumn{2}{|c|}{$\begin{array}{c}\text { Після стимуляції } \\
\text { 3 подальшим періодом } \\
\text { відновлення (група I), } \\
\mathbf{n = 5}\end{array}$} & \multicolumn{2}{|c|}{$\begin{array}{c}\text { Після стимуляції } \\
\text { 3 подальшим періодом } \\
\text { відновлення (група II), } \\
\mathbf{n}=\mathbf{5}\end{array}$} \\
\cline { 2 - 5 } & $\begin{array}{c}\text { Робочий } \\
\text { м'я3 }\end{array}$ & Контроль & Робочий м'яз & Контроль \\
\hline $\mathrm{V}_{4}{ }^{\mathrm{s}}$ & $27,6 \pm 2,7$ & $28,8 \pm 2,3$ & $24,0 \pm 2,07^{*}$ & $13,2 \pm 1,98$ \\
\hline $\mathrm{V}_{3}$ & $57,6 \pm 3,2$ & $59,0 \pm 2,4$ & $46,0 \pm 3,3^{*}$ & $56,0 \pm 2,1$ \\
\hline $\mathrm{V}_{4}$ АТФ & $30,4 \pm 1,4$ & $31,1 \pm 4,1$ & $20,0 \pm 2,1^{*}$ & $15,4 \pm 1,1$ \\
\hline $\mathrm{V}_{3 /} \mathrm{V}_{4}$ & $1,89 \pm 0,13$ & $1,90 \pm 0,12$ & $2,30 \pm 0,14^{*}$ & $3,60 \pm 0,12$ \\
\hline АДФ/О & $1,74 \pm 0,14$ & $1,70 \pm 0,11$ & $1,44 \pm 0,11^{*}$ & $1,67 \pm 0,1$ \\
\hline
\end{tabular}

* Рівень значущості змін досліджуваних показників при $\mathrm{p}<0,05$.

Для пояснення цих результатів можна використати дані, одержані у спортсменів [1, 3]. У легкоатлетів, які спеціалізуються на різних бігових дистанціях, відрізняються домінуючі механізми енергозабезпечення робочих м'язів. Неоднаково змінюються параметри зовнішнього дихання. Спринтери мають нижчі показники затрат енергії, яка виробляється в аеробних процесах. Показано також, що м'язи спортсменів-спринтерів відрізняються від м'язів спортсменів-стаєрів співвідношенням швидкоскорочувальник та повільноскорочуваних м'язових волокон. У спринтерів домінують швидкі м'язові волокна, а у стаєрів повільні, які скорочуються майже вдвічі повільніше [16]. Високі показники аеробної продуктивності у стаєрів пояснюються тим, що аеробна продуктивність в найбільшій мірі проявляється при тих навантаженнях, де $є$ можливість повного забезпечення кисневого запиту і де тривалий час зберігається стійкий рівень $\grave{V O}_{2}$. При переважанні анаеробної продуктивності відсутня можливість забезпечення робочого м'яза адекватною кількістю $\mathrm{O}_{2}$, тому цей тип енергозабезпечення домінує у легкоатлетів спринтерів [1].

Крім зазначених показників, різна реакція на навантаження спостерігалась з боку системи терморегуляції. Тварини групи I на 5 хв стимуляції збільшили ректальну температуру на $0,3^{\circ} \mathrm{C}$, після 10 хв температура зросла на $1^{\circ} \mathrm{C}$ і залишалась підвищеною весь період стимуляції і відновлення. У тварин групи II спостерігали зниження ректальної температури на $0,3^{\circ} \mathrm{C}$ за перші 5 хв стимуляції, далі температура продовжувала знижуватись і на 15 хв була на $1^{\circ} \mathrm{C}$ нижча, ніж вихідна. Після закінчення стимуляції значення ректальної температури тварин групи II повернулися до початкового рівня на 10 хв відновлення. Відповідно до літературних даних [13], 
при збільшенні фрізичного навантаження, продукція тепла в ядрі тіла зменшується, щоб компенсувати поступове збільшення виробництва тепла в м'язах. Однак зниження температури тіла i, відповідно, температурний зсув константи Міхаеліса, зумовлює зменшення швидкості роботи дихальних ферментів, що також визначає зниження $\grave{\mathrm{V}}_{2}[8]$. Це явище відоме, як «удаваний гіпометаболізм» [14].

Описана й інша реакція, коли температура тіла тварин зростає при нульовому навантаженні, одразу після їх розміщення на біговій доріжці. На цей так званий феномен «готовності бігти» припадає продукція більше ніж половини тепла, яке, зазвичай, виробляється при максимальній швидкості бігової доріжки. Цей френомен пов'язують зі стрес-реакцією організму [13]. Існують моделі одноманітних трудових операцій низької інтенсивності, виконання яких супроводжується частішанням дихання, яке в період відновлення змінюється компенсаторним поглибленням. Стресорне тахіпное може призводити до розвитку гіпервентиляції і, як наслідок, гіпокапнії [1]. Отже, стресорною реакцією може пояснити як підвищення температури тіла у тварин групи I, так і гіпервентиляцію.

\section{Література}

1. Бреслав И. С. Дыхание и мышечная активность человека в спорте / И. С. Бреслав, Н. И. Волков, Р. В. Тамбовцева. - М.: Сов. спорт, 2013. - 336 с.

2. БреслаВ И. С. Паттерны дыхания: фризиология, экстремальные состояния, патология / И. С. Бреслав. - Л.: Наука, 1984. - 205 с.

3. Костилл Д. Л. Физиология спорта и двигательной активности / Д. Л. Костилл, Дж. Х. Уилмор. - К.: Олимп. лит., 2001. - 459 с.

4. КостюкоВ А. И. Динамические свойства двигательной системы млекопитающих / А. И. Костюков. - К.: ФАДА, 2007. - 199 с.

5. Мавлиев Ф. А. Краткосрочная адаптация гемодинамики и вариабельности ее параметров в ответ на дозированную физическую нагрузку / Ф. А. Мавлиев, Ф. Р. Зотова, В. А. Демидов // Вестн. спорт. науки. - 2013. - № 6. C. $35-41$.

6. Портніченко В. І. Глікемія як визначальний фрактор шляхів перебудови метаболізму і системи дихання при гіпоксії / В.І.Портніченко, А. Г. Портниченко, А. М. Сидоренко // Патологія. - 2011. - № 2. - С. 52-55.

7. Пожаров В. П. Автоматизированная установка для измерения временных параметров внешнего дыхания и газообмена у мелких лабораторных животных / В. П. Пожаров // Физиол. журн. - 1989. - № 35. - С. 119-121.

8. Фазољые изменения энергетического метаболизма при периодической гипоксии / В. И. Портниченко, В. И. Носарь, А. Г. Портниченко та ін. // Фізіол. журн. - 2012. T. 58, № 4. - C. 3-12.

9. Allen D. G. Skeletal Muscle Fatigue: Cellular Mechanisms / D. G. Allen, G. D. Lamb, H. Westerblad. // Physiological Reviews. - 2008. - Vol. 88. N 1. - P. 287-332.

\section{Висновки:}

1. Виявлено два типи відповіді кисеньтранспортної і енергетичної систем організму експериментальних тварин на гостре фрізичне навантаження (групи I і II).

2. Перший тип відповіді на стимуляцію $\mathrm{m}$. gastrocnemius пов'язаний із незначним зростанням споживання кисню, зростанням вентиляційних показників дихання, гіпертермічною реакцією.

3. Другий тип відповіді на стимуляцію $\mathrm{m}$. gastrocnemius пов'язаний зі зниженням споживання кисню, зниженням вентиляційних і часових показників дихання, гіпотермічною реакцією, ростом вентиляційного еквіваленту.

4. Тварини з першим типом відповіді демонструють повне відновлення показників мітохондріального дихання впродовж періоду найближчого відновлення після стимуляції $m$. gastrocnemius.

Перспективи подальших досліджень будуть спрямовані на виявлення морфоофункціональних особливостей кисеньтранспортної системи організму експериментальних тварин в умовах імітованого фрізичного навантаження, пошук нейрофрізіологічних і молекулярних механізмів, які можуть лежати в основі виявлених двох стратегій відповіді на гостре фрізичне навантаження.

\section{References}

1. Bres/av I. S. Breath and muscular activity of the person in sports / I. S. Breslav, N. I. Volkov, R. V. Tambovtseva. Moscow: Sovetsky sport, 2013. - 336 p.

2. Bres/av I. S. Breathing patterns: physiology, extremes conditions, and pathology / I. S. Breslav, Leningrad: Nauka. 1984. - 205 p.

3. Costil D. L. Physiology of sport and motor activity/ D. L. Costil, J. H. Wilmore. - Kiev: Olimpiyskaya literatura, 2001. - 459 p.

4. Kostyukov A. I. Dynamic properties of the mammalian motor control system / A. I. Kostyukov. - Kyiv: FADA, 2007. - 199 p.

5. Mavliyev F. A. Short-term adaptation of hemodynamics and variability of its parameters in response to the dosed physical loading / F. A. Mavliyev, F. R. Zotova, V. A. Demidov // Vestnik sportivnoy nauki. - 2013. - N 6. - P. 35-41.

6. Portnichenko V. I. Glycemia as the determining factor of metabolic and respiratory system restructuring pathways during hypoxia / V. I. Portnichenko, A. G. Portnychenko, A. M. Sydorenko // Patolohiia. - 2011. - N 2. P. 52-55.

7. Pozharov V. P. Automated plant for time parameters measurement of external respiration and gas exchange in small laboratory / V. P. Pozharov // Fiziologichnyi zhurnal. 2012. - Vol. 35. P. 119- 121.

8. Phase changes in energy metabolism during periodic hypoxia / V. I. Portnichenko, V. I. Nosar, A. G. Portnychenko, et al. // Fiziolohichnyi zhurnal. - 2012. - Vol. 58. - N 4. P. 3-12.

9. Allen D. G. Skeletal Muscle Fatigue: Cellular Mechanisms / D. G. Allen, G. D. Lamb, H. Westerblad // Physiological Reviews. - 2008. -Vol. 88. - N 1. - P. 287-332. 
10. Chance $B$. The respiratory chain and oxidative phosphorylation / B. Chance, Y. Williams / / Adv. Enzymol. 1956. - N 17. - P. 65-134.

11. Coelho A. C. Instantaneous quantification of skeletal muscle activation, power production, and fatigue during cycle ergometry / A. C. Coelho, D. T. Cannon, R. Cao // J. of Appl. Physiology. - 2014. - Vol. 118, N 5. - P. 646-654.

12. Electromyographic models to assess muscle fatigue / M.Gonzбlez-Izal, A. Malanda, E. Gorostiaga, M. Izquierdo // J. of Electromyography and Kinesiology. - 2012. - Vol. 22, N4. - P. 501-512.

13. Exercise Activates Compensatory Thermoregulatory Reaction in Rats: A Modeling Study / [Y. Yoo, M. LaPradd, H. Kline et al.]. // J Appl Physiol. - 2015. - Vol. 119, N 12. - P. $1400-1410$.

14. Hypoxic metabolic response of the golden-mantled ground squirrel / R. C.Barros, M. E. Zimmer, L. G. Branco, W. K. Milsom // J. Appl. Physiol. - 2001. - Vol. 91, N 2. P. $603-612$.

15. Lechauve J. B. Breathing patterns during eccentric exercise / J. B. Lechauve, H. Perrault, B. Aguilaniu // Aguilaniu Respiratory Physiology\&Neurobiology. - 2014. - N 202. - P. 53-58.

16. Medicine \& Science in Sports \& Exercise / G. J. Crowther, S. A. Jubrias, R. K. Gronka, C. E. Kevin // Official Jornal of the American College of Sports Medicine. - 2002. Vol. 34, N 5. - P. 1719-1724.

17. Wilson D. F. Oxygen, $\mathrm{pH}$, and mitochondrial oxidative phosphorylation / D. F. Wilson, D. K. Harrison, S. A. Vinogradov // J. of Appl. Physiology. - 2012. - Vol. 113, N 12. P. $1838-1845$.

theridia@gmail.com
10. Chance $B$. The respiratory chain and oxidative phosphorylation / B. Chance, Y. Williams // Adv. Enzymol. 1956. - N 17. - P. 65-134.

11. Coelho A. C. Instantaneous quantification of skeletal muscle activation, power production, and fatigue during cycle ergometry / A. C. Coelho, D. T. Cannon, R. Cao // J. of Appl. Physiology. - 2014. - Vol. 118, N 5. - P. 646-654.

12. Electromyographic models to assess muscle fatigue / M.Gonzбlez-Izal, A. Malanda, E. Gorostiaga, M. Izquierdo // J. of Electromyography and Kinesiology. - 2012. - Vol. 22, N 4. - P. 501-512.

13. Exercise Activates Compensatory Thermoregulatory Reaction in Rats: A Modeling Study / [Y. Yoo, M. LaPradd, H. Kline et al.]. // J Appl Physiol. - 2015. - Vol. 119, N 12. - P. 1400-1410.

14. Hypoxic metabolic response of the golden-mantled ground squirrel / R. C.Barros, M. E. Zimmer, L. G. Branco, W. K. Milsom // J. Appl. Physiol. - 2001. - Vol. 91, N 2. - P. 603-612.

15. Lechauve J. B. Breathing patterns during eccentric exercise / J. B. Lechauve, H. Perrault, B. Aguilaniu // Aguilaniu Respiratory Physiology\&Neurobiology. - 2014. - N 202. P. 53-58.

16. Medicine \& Science in Sports \& Exercise / G. J. Crowther, S. A. Jubrias, R. K. Gronka, C. E. Kevin // Official Jornal of the American College of Sports Medicine. 2002. - Vol. 34, N 5. - P. 1719-1724.

17. Wilson D. F. Oxygen, $\mathrm{pH}$, and mitochondrial oxidative phosphorylation / D. F. Wilson, D. K. Harrison, S. A. Vinogradov // J. of Appl. Physiology. - 2012. Vol. 113, N 12. - P. 1838-1845. 